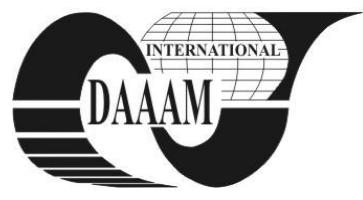

Annals of DAAAM for 2011 \& Proceedings of the 22nd International DAAAM Symposium, Volume 22, No. 1, ISSN 1726-9679 ISBN 978-3-901509-83-4, Editor B. Katalinic, Published by DAAAM International, Vienna, Austria, EU, 2011 Make Harmony between Technology and Nature, and Your Mind will Fly Free as a Bird

\title{
INVESTIGATION OF ENCAPSULANT MATERIAL USED IN PHOTOVOLTAIC MODULES BY THERMAL ANALYSES
}

\author{
POLANSKY, R[adek]; PROSR, P[avel] \& PINKEROVA, M[artina]
}

\begin{abstract}
A paper deals with thermal analysis of ethylene-vinyl acetate encapsulant material used in photovoltaic modules. Properties were analysed in the temperature range from $-70^{\circ} \mathrm{C}$ to $+130{ }^{\circ} \mathrm{C}$. Differential scanning calorimetry and dynamic mechanical analysis were applied. It has been proven that the encapsulant passes through both a glass transition and a melting phase in the range of operation temperatures of the photovoltaic modules. Obtained results show that the encapsulant materials play essential role from the operation point of view and its properties can by no means be underestimated.
\end{abstract}

Key words: photovoltaics, EVA, encapsulant, glass transition, thermal analyses

\section{INTRODUCTION}

Renewable sources of energy are currently an integral part of our lives. Solar energy as one of these sources doesn't work without reliable photovoltaic modules. Studies concerning the photovoltaic modules mostly deal with e.g. increase of efficiency of the solar energy transformation (Hocine, 2009), with problems connected with decrease of manufacturing costs (Espinosa, 2010) or with influence of the photovoltaic modules on power grid (Seme, 2009). Not such an interest is paid to reliability of these modules. Considering that manufacturers usually guarantee the module lifetime at the least for 20 years, it is necessary to take this into account. Hence the main aim of the paper is to analyze mechanical properties together with thermal stability of ethylene-vinyl acetate (EVA) film used for encapsulation of the photovoltaic modules. Chosen commercially available ethylene-vinyl acetate was analyzed by differential scanning calorimetry and dynamic mechanical analysis. According to the obtained results, the influence of the encapsulant to the total reliability of the photovoltaic module cannot be underestimated.

\section{BACKGROUND}

The typical photovoltaic module consists of several main layers (see Fig. 1). The part, to which the most attention is paid, is the solar cell itself. As it is very brittle under the common environmental exposure, it is necessary to protect it during its operation. It is obvious from Fig. 1 that the solar cell is shielded from the mechanical stress (i.e. stress during the transport, installation or operation stress - wind blast, hailstones or dust influence) by the protective glass sheet from the front. From the back the cell is provided by backing protective sheet mostly made of plastics. All parts are hermetically sealed to one compact unit by the help of two layers of above mentioned EVA film. This film is absolutely essential from the operation point of view, it protects the solar cell from the atmosphere influences in the first place, but it also protects it from the influence of vibrations or humidity etc.

EVA film is placed on the whole surface of the front and back side of the photovoltaic module. Its application on the front side of the modules during the manufacturing is illustrated in the Fig. 2 (the cells are in this manufacture stage turned up side down).

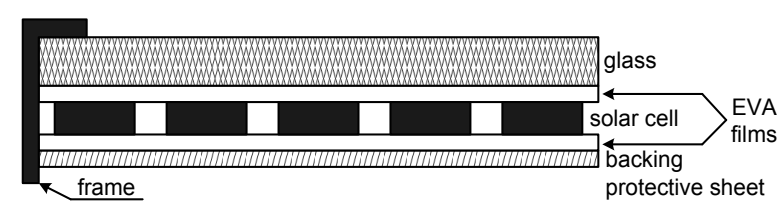

Fig. 1. Cross-section of photovoltaic module

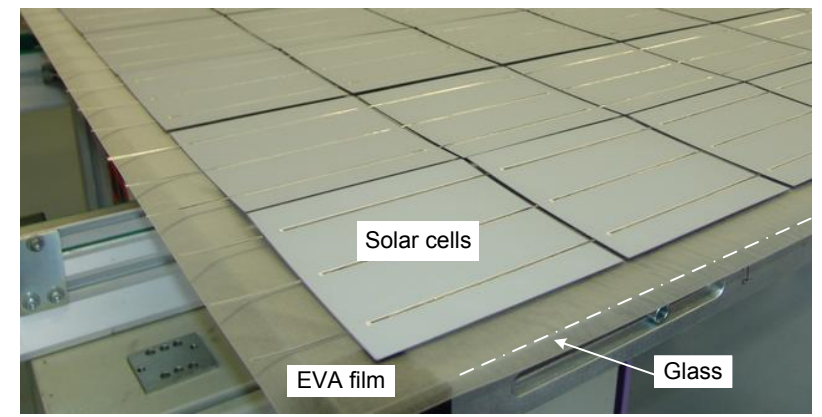

Fig. 2. Photovoltaic module manufacturing

Considering the fact that sunrays must firstly pass through the glass sheet and then through the EVA film before their incidence on the solar cell itself, it is important to deal with the properties of these sheets in more details. Regarding the reliability, there is to be focused mainly on organic ethylenevinyl acetate. Its properties, processing and mechanisms of degradation have been already described by e.g. Klemchuk (Klemchuk, 1997), Agroui (Agroui, 2006; 2007) or Kempe (Kempe, 2007). Most of the authors agree that EVA application in the case of encapsulation is the matter of low price more than its good combination of properties. That is also the main reason why this paper is focused on these problems.

\section{RESULTS AND DISCUSSION}

\subsection{Dynamic mechanical analysis}

The solar cells can be exposed to extreme low temperatures (in some cases even around -30 up to $-40{ }^{\circ} \mathrm{C}$ ); particularly during the winter season. At such low temperatures ethylenevinyl acetate reaches the glass transition temperature (Kempe, 2007) and elastic material thus changes into solid and very brittle. Hence it is very important to monitor glass transition temperature and the mechanical properties of EVA film by dynamic mechanical analysis (DMA), since it is considered as the most accurate method for this purpose. DMA results are presented in Fig. 3, where both the crosslinked and the uncrosslinked samples of tested EVA are shown. As Fig. 3 also illustrates, there is marked increase of storage modulus (almost twice as high values) due to the crosslinking. Also slight shift of all analyzed temperatures towards the negative temperatures 
was observed. The onset temperature of decrease of the storage modulus, which is from the operation point of view the most important property in the case of the photovoltaic modules, stabled at approx. $-40{ }^{\circ} \mathrm{C}$ after the crosslinking. This is also the temperature often declared by EVA film manufacturers as the thermal minimum for its application. It needs to be known that eventual mechanical stress of module (e.g. wind blasts, heavy snow cover etc.) at very low temperatures causes measurable changes in the inner structure much earlier.

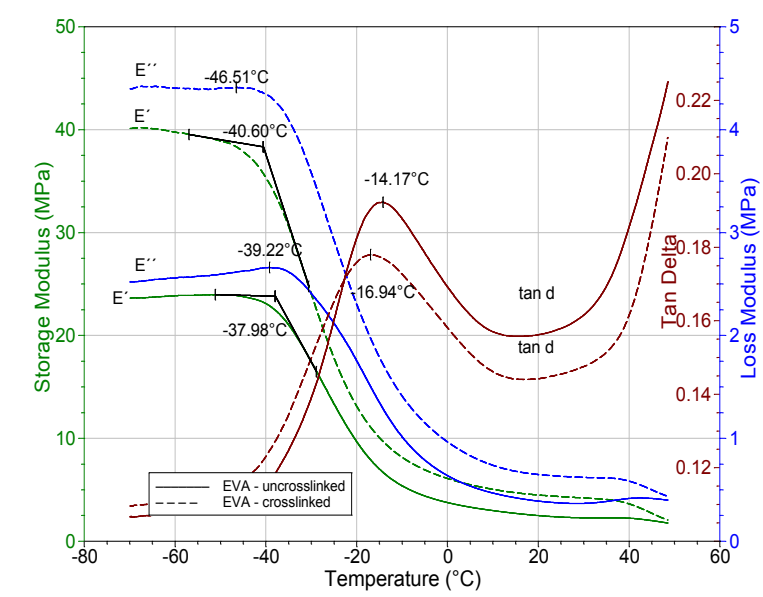

Fig. 3. DMA results of crosslinked and uncrosslinked EVA

These changes are expressed by the maximum of dissipation factor $(\tan \delta$ ). Its reaching (from positive to negative temperatures) means that EVA film begins to transform from its flexible state into a brittle state and it is no longer able to respond to the mechanical energy caused by the eventual mechanical stress of the module. This energy is then changed in the inner structure of the material into the thermal losses, which are detected by the high value of $\tan \delta$. The maximum value of $\tan \delta$ in the case of the crosslinked EVA was observed at the temperature of $-16.9^{\circ} \mathrm{C}$.

\subsection{Differential scanning calorimetry}

The crosslinked sample of EVA copolymer was analyzed also by differential scanning calorimetry (DSC) to provide the results of melting temperatures. The results are shown in Fig. 4. It is obvious that from $30{ }^{\circ} \mathrm{C}$ DSC recorded the beginning of two overlapping endothermic peaks (peak maximum at $45.7^{\circ} \mathrm{C}$ and $66.7^{\circ} \mathrm{C}$ ). It is the melting of two populations of crystalline perfection. With reference to Agroui (Agroui, 2006), the lower of those two temperatures refers to melting of imperfect, small crystallites, which are effects of the integration of the vinyl acetate into the polyethylene structure, whereas the higher temperature refers to the melting of larger and more regularly formed crystallites in the polyethylene.

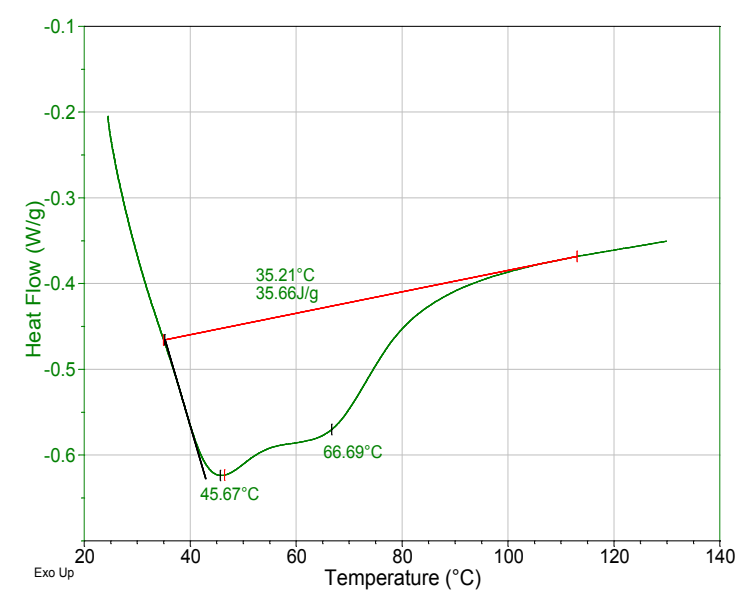

Fig. 4. DSC of crosslinked EVA

\section{CONCLUSION}

It has been proven that the encapsulant passes through both the glass transition and the melting phase in the range of operation temperatures of the photovoltaic modules. According to the obtained results, EVA film is getting more brittle, i.e. more sensitive to mechanical stress when moving towards the negative temperatures. On the other hand, at the positive temperatures, vinyl acetate crystallites start to melt even at the temperatures around $46{ }^{\circ} \mathrm{C}$, polyethylene crystallites at $67^{\circ} \mathrm{C}$. These findings are not very desired from the operation point of view. Due to instability of the encapsulant film there is a possibility of delamination during the operation, which can threaten directly the solar cell itself and thus the whole photovoltaic module. Even though some studies point out that there are more suitable encapsulant materials, e.g. silicon based materials (Kempe, 2007), (Muirhead, 1995), the EVA films still have dominance in the photovoltaic industry. The next step of this project will consist in testing of EVA film after accelerating laboratory aging (high temperature, UV radiation, moisture etc.).

\section{ACKNOWLEDGEMENTS}

This article was carried out with the support of Ministry of Education, Youth and Sports of Czech Republic, MSM 4977751310.

\section{REFERENCES}

Agroui, K.; Maallemi, A.; Boumaour, M.; Collins, G.; Salama, M. (2006). Thermal stability of slow and fast cure EVA encapsulant material for photovoltaic module manufacturing process. Solar Energy Materials \& Solar Cells, Vol. 90, No. 15, September 2006, p. 2509-2514, ISSN 0927-0248

Agroui, K.; Belghachi, A.; Collins, G.; Farenc, J. (2007) Quality control of EVA encapsulant in photovoltaic module process and outdoor exposure. Desalination, Vol. 209, No. 1-3, April 2007, p. 1-9, ISSN 0011-9164

Espinosa, N.; García-Valverde, R.; García-Cascales, M. S.; Urbina, A. (2010). Towards low-cost manufacturing of organic solar cells: multi-criteria assessment of fabrication technologies. Proceedings of ICREPQ '10, Granada, ISBN 978-84-613-7543-1

Hocine, D.; Belkaid, M.S.; Lagha, K. (2009). Optimization of $\mathrm{SnO}_{2}$-Si heterostructure elaborated by APCVD for solar energy conversion. Proceedings of ICREPQ '09, Valencia, ISBN 978-84-612-8014-8

Kempe, M. D.; Jorgensen, G. J.; Terwilliger, K. M.; McMahon, T. J.; Kennedy, Ch. E.; Borek, T. T. (2007). Acetic acid production and glass transition concerns with ethylenevinyl acetate used in photovoltaic device. Solar Energy Materials \& Solar Cells, Vol. 91, No. November 2007, p. 315-329, ISSN 0927-0248

Klemchuk, P.; Ezrin, M.; Lavigne, G.; Halley, W.; Galica, J.; Agro, S. (1997). Investigation of the degradation and stabilization of EVA-based encapsulant in field-aged solar energy modules. Polymer Degradation and Stability, Vol. 55, No. 3, March 1997, p. 347-365, ISSN 0141-3910

Muirhead, I.J.; Hawkins, B.K. (1995). An assessment of photovoltaic power in the Telstra network. Proceedings of Annual Conference of the Australian and New Zealand Solar Energy Society. Available from: http://www.tele power.com.au/Solar95.PDF. Accessed: 2011-01-12

Seme, S.; Štumberger, G.; Pihler, J. (2009). Predicting daily distribution of solar irradiation by neural network. Proceedings of ICREPQ '09, Valencia, ISBN 978-84-6128014-8 